\title{
AS REPERCUSSÕES DA SÚMULA VINCULANTE N. 4 NO DIREITO DO TRABALHO
}

\author{
Jiulian César Belarmino Pandolfi \\ jiulianpandolfi@adv.oabsp.org.br
}

\section{RESUMO}

A possibilidade, ou não, de se utilizar o salário mínimo como indexador de base de cálculo para o pagamento do adicional de insalubridade sempre foi um tema muito polêmico e instigante. Para tentar uniformizar os diversos entendimentos sobre esse assunto o Supremo Tribunal Federal aprovou a súmula vinculante n. 4. O presente estudo aborda exatamente o contexto jurídico que deu origem à súmula vinculante n. 4 e suas repercussões no direito do trabalho. $\mathrm{O}$ trabalho demonstra também que a súmula vinculante n. $^{\circ} 4$ não pacificou a polêmica jurisprudencial sobre a possibilidade de se indexar a base de cálculo do adicional de insalubridade ao salário mínimo. Antes, porém, serão abordados, com uma visão crítica, alguns aspectos gerais sobre as súmulas vinculantes, como, por exemplo, seu conceito, suas principais características e seus efeitos. Trata-se de uma pesquisa que evidencia alguns importantes pontos de vista sobre as súmulas vinculantes, bem como todo o imbróglio que envolve a súmula vinculante n. 4 , servindo de uma ótima ferramenta para o bom jurista.

Palavras chaves: Direito do trabalho, adicional de insalubridade, súmula vinculante n. 4.

\begin{abstract}
The possibility of using or not using the minimum wage as an indexer of calculation basis for the insalubrity premium has always been a very controversial and provocative topic. In order to try to unify the different understandings on this issue the Supreme Federal Court has approved the binding precedent $n$. 4. This paper exactly addresses the legal context that originated the binding precedent n. 4 and its repercussions on Labor Law. The work also shows that the binding precedent $\mathrm{n} .4$ has not pacified the jurisprudential controversy about the possibility of indexing the calculation basis for the hazard pay to the minimum wage. Firstly, however, it will be addressed with a critical view, some general aspects about the binding precedents, such as, for example, their concepts, their main characteristics and their effects. This is a research that evidence some important points of view about the binding precedents, as well as and the tangled web that involves the binding precedent n. 4 , serving as a great tool for the good jurists.
\end{abstract}

\section{INTRODUÇÃO}

O art. 192 da CLT dispõe que o exercício de trabalho em condições insalubres, acima dos limites de tolerância estabelecidos pelo Ministério do Trabalho, assegura a percepção, pelo obreiro, de adicional de insalubridade de 40\% (grau máximo), 20\% (grau médio), 10\% (grau mínimo) do salário mínimo da região.

A norma legal em apreço utiliza o salário mínimo da região como base para incidência de percentagem visando satisfazer adicional de insalubridade. 
Acontece que, a parte final do disposto no inciso IV, do art. $7^{\circ}$, da $\mathrm{CF} / 88$, proíbe que o salário mínimo seja vinculado para qualquer fim.

Tendo em vista essa proibição constitucional, pergunta-se: a parte final do disposto no art. 192 da CLT foi recepcionada pela Carta Magna? Essa indagação causou enorme alvoroço na jurisprudência. Os Tribunais brasileiros nunca chegaram a um consenso sobre a matéria.

Para resolver esse problema, o STF aprovou a súmula vinculante n. 4, que foi publicada no Diário Oficial da União, no dia 09/05/2008. A citada súmula determina: "salvo nos casos previstos na Constituição, o salário mínimo não pode ser usado como indexador de base de cálculo de vantagem de servidor ou de empregado, nem ser substituído por decisão legal".

Será que a aprovação e publicação da súmula vinculante n. 4 resolveu o dilema acerca da constitucionalidade, ou não, da vinculação do salário mínimo para pagamento do adicional de insalubridade? Qual o contexto jurídico que fez nascer mencionada súmula? Em última análise o que ela objetiva? Quais foram suas repercussões para o Direito do Trabalho?

Para solucionar essas indagações o presente estudo primeiramente esclarecerá alguns aspectos gerais sobre as súmulas vinculantes, como, por exemplo, seu conceito, ocasião em que será demonstrado que tais súmulas são verbetes abstratos que, após aprovados pelo STF, vinculam os demais órgãos do Poder Judiciário e da Administração Pública.

Também serão delineadas, de uma forma crítica, as principais características das súmulas vinculantes, entre as quais se destacam o fato de serem aprovadas e executadas por um único órgão, o STF, e sua força vinculativa.

Após, será demonstrado que as súmulas vinculantes provocaram uma ruptura no modelo do ordenamento jurídico brasileiro no qual, a partir de então, imiscuiu-se características distorcidas do common law.

Adiante, o trabalho irá revelar que a aprovação da súmula vinculante n. 4 ocorreu para tentar pacificar a polêmica jurisprudencial que existia sobre a base de cálculo do adicional de insalubridade.

É que, para alguns juristas a referida base de cálculo podia ser vinculada ao salário mínimo, para outros essa possibilidade desrespeitaria o disposto na parte final do inciso IV, do artigo $7^{\circ}$, da Constituição Federal.

A dissertação abordará especificamente a decisão do Pleno do STF proferida no Recurso Extraordinário n. ${ }^{\circ}$ 565.714, pois foi exatamente esse recurso que, interposto por policiais militares do Estado de São Paulo, provocou a aprovação da súmula vinculante n. ${ }^{\circ} 4$. 
O estudo mostrará que a aprovação da súmula vinculante n. ${ }^{\circ} 4$ repercutiu no Direito do Trabalho fazendo com que o C.TST alterasse várias vezes sua orientação sobre a possibilidade de se indexar a base de cálculo do adicional de insalubridade ao salário mínimo.

Por fim, será demonstrado que a questão não está pacificada, o que poderá eventualmente ocorrer após ser proferida decisão final na Reclamação n. ${ }^{\circ}$ 6266, em que se discute a referida indexação, ou até mesmo por meio do ajuizamento de eventual mandado de injunção.

\section{AS SÚMULAS VINCULANTES \\ 1.1 CONCEITO.}

Com a evolução da tecnologia da informação e a revolução sócio-econômica e cultural em massa, criou-se um novo modelo de sociedade.

Segundo Angeluci (2009) é a chamada "sociedade da informação", que fez gerar não só no Brasil, mas no mundo, a criação de novos direitos e, por conseqüência, trouxe uma multiplicidade de eventos danosos que findaram em um aumento considerável de ações.

A própria promulgação da Constituição Federal de 1988 trouxe consigo vários direitos individuais, o que provocou um aumento significativo no número de ajuizamento de ações, pois as pessoas passaram a buscar cada vez mais a tutela do Poder Judiciário na defesa de seus interesses.

\footnotetext{
O povo ampliou o conhecimento sobre o significado de sua cidadania e passou a exercê-la, desde o voto até a possibilidade de requerer seus direitos perante o Estado (e, inclusive, contra o Estado), e exigir deste um serviço adequado e eficiente. $\mathrm{O}$ aumento do número de feitos, portanto, se dá em face do conflito redemocratização versus não efetivação dos direitos democráticos constitucionalmente determinados (CRUZ JUNIOR, 2009).
}

Acontece que, às vezes milhares de pessoas ajuízam ações que, embora contenham pedidos idênticos, ao final apresentam resultados diferentes.

Essas decisões não uniformes causam uma insegurança jurídica aos jurisdicionados, que, de certo modo, ficam à mercê do entender íntimo de cada magistrado sobre o caso proposto.

Tal fato também possibilita a interposição de muitos recursos, sobrecarregando o Poder Judiciário, tornando-o lento. 
Se não bastasse, as decisões díspares contribuem para o enfraquecimento da economia do país, pois, em tese, coíbem o investimento estrangeiro em setores ainda não desenvolvidos, que teriam maiores chances de suscitarem a tutela jurisdicional.

Desse modo, o Estado passou a advogar a implantação das súmulas vinculantes fundamentando-se exatamente na necessidade de se outorgar maior segurança jurídica aos jurisdicionados, nacionais ou estrangeiros.

Para Maués, Fonseca e Rego (2009), “diante da divergência judicial em torno da aplicação de determinada norma, a edição de súmulas vinculantes pelo STF traria a uniformização da jurisprudência sobre a matéria, eliminando as incertezas quanto ao entendimento esposado pelos tribunais".

Assim, a esperança do Poder Constituinte Derivado era que as súmulas vinculantes uniformizassem os julgamentos e impedissem a interposição de recursos, conferindo maior agilidade ao Poder Judiciário.

Nas palavras de Lobo (2009), "uma vez aplicado o entendimento da súmula na sentença de primeiro grau, saberia, de antemão, a parte sucumbente que os Tribunais não poderiam reformá-la, sob pena de seu acórdão ser objeto de reclamação perante o Supremo Tribunal Federal”.

Além disso, o Estado, por meio do Judiciário, consoante Pedron (2009) "proporcionaria uma ordem de estabilidade causada pela previsibilidade e celeridade na aplicação das normas jurídicas e pela garantia da obrigatoriedade dos contratos, minimizando o risco das atividades econômicas".

Desta feita, em 08 de dezembro de 2004 foi promulgada a Emenda Constitucional $\mathrm{n}$. 45, que incluiu na $\mathrm{CF} / 88$ o art. 103- $\mathrm{A}^{1}$, que outorgou ao STF a possibilidade de aprovar súmula de efeito vinculante.

\footnotetext{
1 Art. 103-A. O Supremo Tribunal Federal poderá, de ofício ou por provocação, mediante decisão de dois terços dos seus membros, após reiteradas decisões sobre matéria constitucional, aprovar súmula que, a partir de sua publicação na imprensa oficial, terá efeito vinculante em relação aos demais órgãos do Poder Judiciário e à administração pública direta e indireta, nas esferas federal, estadual e municipal, bem como proceder à sua revisão ou cancelamento, na forma estabelecida em lei.

$\S 1^{\circ}$ A súmula terá por objetivo a validade, a interpretação e a eficácia de normas determinadas, acerca das quais haja controvérsia atual entre órgãos judiciários ou entre esses e a administração pública que acarrete grave insegurança jurídica e relevante multiplicação de processos sobre questão idêntica.

$\S 2^{\circ}$ Sem prejuízo do que vier a ser estabelecido em lei, a aprovação, revisão ou cancelamento de súmula poderá ser provocada por aqueles que podem propor a ação direta de inconstitucionalidade.

$\S 3^{\circ}$ Do ato administrativo ou decisão judicial que contrariar a súmula aplicável ou que indevidamente a aplicar, caberá reclamação ao Supremo Tribunal Federal que, julgando-a procedente, anulará o ato administrativo ou cassará a decisão judicial reclamada, e determinará que outra seja proferida com ou sem a aplicação da súmula, conforme o caso.
} 
Assim sendo, aprovada uma súmula, na forma do referido dispositivo em questão, ou seja, vinculante, como o próprio nome denota, seus efeitos vinculam os demais órgãos do Poder Judiciário e da Administração Pública.

Portanto, as súmulas vinculantes são enunciados abstratos que, após aprovados pelo STF, vinculam os demais órgãos do Poder Judiciário e da Administração Pública, no exercício de suas respectivas competências constitucionais.

As súmulas vinculantes contribuíram para que a taxa de congestionamento de processos que aguardam julgamento nos Tribunais brasileiros permanecesse praticamente estável nos últimos anos, mas não conseguiram acabar com o problema, pois, segundo dados do Conselho Nacional de Justiça:

\begin{abstract}
Durante o ano de 2008 , no $1^{\circ}$ grau da Justiça Estadual tramitaram mais de 45 milhões de processos, sendo que dentre eles 33 milhões já estavam pendentes de julgamento desde o final do ano anterior. Neste mesmo período foram sentenciados 9,3 milhões de processos, ou seja, apenas $20 \%$ do quantitativo total em tramitação. A conseqüência natural diante de tal volume de estoque pendente é uma dificuldade em reduzir a taxa de congestionamento, tendo em vista o constante aumento do número de processos ingressados e o aumento na carga de trabalho. No primeiro grau a carga de trabalho dos juízes chegou a quase 5,3 mil processos por magistrado com uma taxa de congestionamento que permanece na faixa de $80 \%$ praticamente sem variações desde 0 ano $2004^{2}$. (g.n.)
\end{abstract}

Entretanto, é importante ressaltar que o acúmulo de processos nos Tribunais brasileiros dificilmente seria disseminado apenas com o advento das súmulas vinculantes.

O problema é complexo, decorre da evolução tecnológica, do fortalecimento dos direitos individuais, do grande número de ações ajuizadas, da falta de infraestrutura, quadro que é agravado pela observação às leis, ainda arcaicas, que não acompanharam as evoluções da vida moderna.

A crise no Poder Judiciário é, essencialmente, a da demora na entrega da prestação jurisdicional, em face do volume de ações que são submetidas à sua apreciação. Ela é decorrente das formas arcaicas adotadas pelo Direito Processual, pelo grande número de recursos que o sistema permite, pela falta de juízes para o atendimento da demanda judicial, pelas deficiências em sua estrutura organizacional com falta de verbas para o seu funcionamento, e por ausência de boa vontade do Estado em adotar uma legislação mais simples e adequada aos fenômenos de comunicação e de celeridade da época contemporânea (DELGADO, 2009).

\footnotetext{
2 CONSELHO NACIONAL DE JUSTIÇA. A Justiça em números. 2003. Disponível em: $<$ http://www.cnj.jus.br/index.php?option=com_content\&view=article\&id=5242:justiemnos2003\&catid=206:just iem-nos\&Itemid=775>. Acesso em: 02 nov. 2009.
} 
Por outro lado, no período entre 2004 e 2009 a taxa de investimento estrangeiro direto (IED), no Brasil, em relação ao PIB, (produto interno bruto) oscilou sobremaneira, conforme demonstrado na tabela abaixo.

Tabela 1- Taxa de investimento estrangeiro direito em relação ao PIB:

\begin{tabular}{|l|l|l|}
\hline ANO & $\begin{array}{l}\text { US\$ } \\
\text { BILHÕES }\end{array}$ & PIB \\
\hline 2000 & 32,779 & 5,44 \\
\hline 2001 & 22,457 & 4,41 \\
\hline 2002 & 16,59 & $-3,61$ \\
\hline 2003 & 10,144 & 2 \\
\hline 2004 & 18,166 & 3,01 \\
\hline 2005 & 15,066 & 1,91 \\
\hline 2006 & 18,782 & 1,91 \\
\hline 2007 & 33,705 & 2,7 \\
\hline 2008 & 43,886 & 3,27 \\
\hline 2009 & 25 & 1,67 \\
\hline $2010 *$ & 45 & - \\
\hline
\end{tabular}

Fonte: <www.corecon-rj.org.br/Series_BP.asp?...Investimento+estrangeiro>. Acesso em: 11 de nov. 2009. (*) Previsões de ECONOMIA BR em dezembro de 2009.

Desse modo, o não investimento de capital estrangeiro, no Brasil, não tem como fundamento a existência de decisões judiciais não uniformes.

\subsection{CARACTERÍSTICAS.}

Uma característica marcante das súmulas vinculantes é exatamente sua força vinculativa, tão evidente que, quando desrespeitada, permite que seja efetivado pedido de reclamação junto ao STF.

É importante observar que qualquer pessoa pode suscitar reclamação diretamente ao STF, sem que os Tribunais inferiores apreciem a questão de afronta ao texto sumular.

Tal fato é um contrassenso, por dois motivos.

Primeiro porque, não é cabível reclamação ao STF quando ocorre desrespeito ao próprio texto constitucional, pois, neste caso, a pessoa que se sentir lesada pode apenas e tão somente interpor recurso extraordinário (CF/88, art. 102, inc. III, alínea "a"). 
Segundo porque, a possibilidade acima citada pode gerar um acúmulo de reclamações constitucionais no STF superior em relação ao que existia antes do surgimento das súmulas vinculantes, e sem a possibilidade dessas reclamações serem revistas.

"O que se questiona aqui é se realmente a súmula vinculante poderia proporcionar maior agilidade ou maior entrave ao processo e suas garantias, arriscando, assim, o comprometimento de princípios fundamentais ao processo", Lopes (2009).

Ferreira e Moura (2010) não concordam com a força vinculativa das súmulas, tanto que afirmam que as súmulas vinculantes "vieram por engessar o juiz de primeira instância, o qual, até então, era livre para dar ao litígio a solução adequada relativamente ao seu convencimento".

Contundente, Didier Júnior (2009) afirma que as súmulas vinculantes representam a ditadura da toga, “onde a vontade, na maioria das vezes, arbitrária, subjetiva, individual e antidemocrática do plenário do STF submete toda a nação, sem nenhum traço de respeito, ao regime democrático".

Além da força vinculativa, as súmulas vinculantes possuem outra característica importante, qual seja, elas são aprovadas e executadas exclusivamente pelo STF, isto é, o órgão que cria a súmula vinculante é o mesmo que a executa.

Para alguns juristas essa característica faz com que as súmulas vinculantes possam ser consideradas inconstitucionais.

É que, a própria Constituição impõe limites ao Poder Constituinte Derivado.

De modo que, não pode ser objeto de Emenda Constitucional a "proposta de emenda tendente a abolir: a forma federativa de Estado; o voto direito, secreto, universal e periódico, a separação dos Poderes; os direitos e garantias individuais"3.

É claro que o texto não proíbe apenas emendas que expressamente declarem: "fica abolida a Federação ou a forma federativa de Estado", "fica abolido o voto direito...", "passa a vigorar a concentração de Poderes", ou ainda "fica extinta a liberdade religiosa, ou de comunicação..., ou o habeas corpus, o mandado de segurança...". A vedação atinge a pretensão de modificar qualquer elemento conceitual da Federação, ou do voto direito, ou indiretamente restringir a liberdade religiosa, ou de comunicação ou outro direito e garantia individual; basta que a proposta de emenda se encaminhe ainda que remotamente, "tenda" (emendas tendentes, diz o texto) para a sua abolição (SILVA, 2000, p. 69).

3 Art. $60, \S 4^{\circ}$, da CF/88. 
Embora não seja atribuição do STF legislar, não se pode negar que, ao ser conferido efeito vinculante à súmula esta se assemelha sobremaneira com a $\mathrm{lei}^{4}$, assumindo o órgão criador características tipicamente legislativas.

Desta feita, as súmulas vinculantes tenderiam a abolir a separação dos Poderes, sendo este um forte argumento contra a constitucionalidade das mesmas.

Não obstante as veementes críticas apontadas, o fato é que as súmulas vinculantes foram instituídas no ordenamento jurídico brasileiro e, para alguns estudiosos, a aprovação das mesmas se desenvolve no estrito exercício jurisdicional.

\begin{abstract}
Não haveria nas súmulas vinculantes nenhuma característica que lhe retirasse o traço marcante da jurisdição, sem poder de veicular pautas de condutas a serem seguidas por toda a sociedade, limitando-se a resumir entendimentos declaratórios uniformizados do STF acerca de validade, interpretação e eficácia de leis ou atos normativos (GOUVEIA, 2009).
\end{abstract}

\title{
1.3 EFEITOS.
}

O sistema jurídico brasileiro nos dizeres de Hartmann (2010) é "calcado nas premissas estabelecidas pela civil law, de origem romano-germânica, que considera como fonte normativa do Direito apenas as leis".

No início da adoção desse tipo de sistema, pensou-se que o intérprete resolveria todos os problemas pela simples subsunção do caso concreto à lei.

Ocorreria uma espécie de aplicação dos princípios das ciências exatas no direito, sendo possível a previsão, pelo legislador, de todas as hipóteses concretas.

Embora isso não tenha ocorrido, o sistema civil law não ficou de lado, pois ainda é o sistema predominante no ordenamento jurídico brasileiro.

Tanto é verdade que o juiz é obrigado a fundamentar sua decisão (art. 93, inc. IX, $\mathrm{CF} / 88$ ), inclusive não são raras as ocasiões em que o julgador aprecia o objeto do processo tendo em conta apenas os dispositivos legais citados pelas partes.

Todavia, ao longo dos tempos, passou-se a dar maior ênfase nas maneiras pelas quais os casos passaram a ser decididos, de modo que o julgador também passou a se orientar pelas decisões anteriores proferidas pelos Tribunais Superiores sobre casos análogos à demanda objeto de sua decisão.

\footnotetext{
4 A aprovação, modificação ou revogação da súmula vinculante se opera apenas por intermédio das pessoas legitimadas à propositura direta de inconstitucionalidade $\left(\mathrm{CF} / 88\right.$, art. 103-A, $\left.\S 2^{\circ}\right)$.
} 
Esses entendimentos dos Tribunais, denominados jurisprudência, quando muitos e uniformes, provocavam o surgimento das súmulas. Estas, por seu turno, consolidaram-se como fonte de orientação aos magistrados.

Entretanto, após a Emenda Constitucional n. 45 foram instituídas, no Brasil, as súmulas com efeito vinculante.

Qual é o efeito da instituição das súmulas vinculantes?

Uma ruptura. Em verdade o surgimento de um novo modelo de sistema jurídico.

No sistema common law uma decisão a ser tomada em um caso concreto depende necessariamente da verificação do inteiro teor das decisões adotadas para casos anteriores. As decisões anteriores servem para decidir os casos concretos, sendo fonte normativa do direito.

\begin{abstract}
A aplicação da regra do precedente exige, da parte do jurista anglo-americano, o emprego da "técnica das distinções", a qual é considerada a técnica fundamental do common law. Por seu intermédio, distingue-se, nas reasons dadas pelos julgadores como fundamentos de suas decisões, aquilo que constitui o suporte necessário da decisão (a ratio decidendi do julgamento) daquilo que o juiz pode ter declarado sem necessidade absoluta (aquilo que constitui obiter dictum). Somente a ratio decidendi constitui uma regra jurisprudencial que se incorpora ao direito e deve, a este título, ser seguida no futuro. (PIMENTA, 2010).
\end{abstract}

Portanto, o interprete verifica se o inteiro teor das decisões anteriores é aplicável ao caso posto sob julgamento. Em caso positivo, o Tribunal segue o raciocínio usado na decisão anterior (princípio conhecido como stare decisis).

Entretanto, se o Tribunal concluir que a controvérsia em exame é fundamentalmente diferente de todos os casos anteriores, decidirá como "assunto de primeira impressão" (matter of first impression, em inglês).

Essa decisão será feita pelo julgador com liberdade, de modo que essa "nova" decisão, de certa maneira, "cria" o direito, tornando-se um precedente e vinculará os tribunais nos julgamentos futuros.

Ao contrário do que acontece com o precedente do common law, ao ser atribuído efeito vinculante à súmula, esta perde o caráter substancial que lhe deu origem, perde sua essência.

Esse caráter essencial consiste exatamente no laço até então existente com os julgamentos anteriores, constantes e uniformes, sobre determinado tema.

Assim sendo, o verbete sumular, de caráter geral e abstrato, poderá ser aplicado em vários casos, sem que se verifique o inteiro teor da decisão que lhe deu origem, bastando, para 
tanto, que o caso concreto, posto em julgamento, contenha em seu bojo o respectivo tema sumular.

Vale dizer, a partir do nascedouro do efeito vinculante das súmulas o ordenamento jurídico brasileiro foi jungido por um novo modelo de sistema jurídico, em que se imiscui no sistema civil law características distorcidas do common law.

A discussão presente está baseada na globalização das sociedades, e como conseqüência, as influências são recíprocas entre ambos os sistemas de direito, e à medida que as sociedades se globalizam, o mesmo acontece com a prática legal, em que lei e jurisprudência são postas na mesma balança (FAIS; SILVA; 2010).

Essa questão é de extrema complexidade, uma vez que à medida que a súmula passa a vincular seus efeitos obriga a que o juiz proceda a uma ruptura interna de pré-conceitos meramente positivistas.

Pode-se afirmar que, agora, a hermenêutica, em especial daquele que possui a tarefa de aplicar a súmula vinculante, deverá ser outra, não de qualquer jeito, mas necessariamente vinculado ao "novo" sistema.

Por isso, o magistrado não deve aplicar a súmula vinculante ao caso concreto de forma simplista, o que ocorre quando o simples tema do enunciado da súmula vinculante se transforma em um dogma imutável, apenas por ser parecido com o tema objeto do caso concreto.

É cediço que a súmula vinculante e o caso concreto podem possuir o mesmo "tema", todavia, ainda assim podem não se encaixar como uma luva.

Assim, mesmo possuindo status constitucional, o efeito vinculante das súmulas deve ser visto com reservas pelo julgador.

\begin{abstract}
Antes de tudo, ao estar diante da aplicação de uma súmula, o intérprete deve examinar o contexto, isto é, a similitude do "caso" que a súmula quer abarcar, evitando, assim, a subsunção metafísica própria do modelo positivista-exegético. Interpretar é aplicar. Subsunções escondem a singularidade dos casos e a súmula, ao pretender construir conceitos universalizantes, poderá sacrificar a especificidade do caso subanálise, que é sempre único, irrepetível (STRECK apud BONAVIDES, 2008, p. 429).
\end{abstract}

É dever imposto ao juiz dirimir o caso por meio de uma decisão jungida por uma hermenêutica firme, segura e polida. Constata-se esse tipo de decisão quando há uma perfeita engrenagem entre a súmula vinculante e o caso concreto posto em julgamento.

O exercício de decidir deve ser feito observando-se de um lado o contexto histórico gerador da súmula e, de outro, as peculiaridades do caso concreto. 
Também não se pode deixar de lado a realidade social, econômica, cultural e histórica em que o julgamento é realizado, pois o enunciado da súmula deve sempre ter efetividade contemporânea.

É de extrema necessidade que o juiz compreenda corretamente o contexto histórico, social, político, econômico, entre outros, que deu azo ao surgimento da súmula vinculante. $\mathrm{O}$ magistrado deve ter em vista os motivos determinantes para a aprovação da súmula vinculante, e o que especificamente pretendeu-se que com ela fosse abarcado.

De outra banda, ao julgar o juiz deve obrigatoriamente demonstrar que as especificidades do caso examinado coincidem exatamente com os fundamentos das decisões que autorizaram a criação do verbete sumular.

Deve ser bem nítida e evidente, sem margem para dúvidas, a autorização advinda da peculiaridade do caso concreto à aplicação da súmula vinculante.

"Destarte, verificando discordância entre os fatos ou o direito aplicável à situação que originou o litígio e os fatos ou o direito regente das situações ensejadoras da súmula, é de se declará-la inaplicável”, (Caribe, 2010).

Assim agindo o juiz evitará que sua sentença se transforme em um mero instrumento de aplicação indevida de súmula vinculante. O interprete deve, isto sim, superar a clássica visão sobre o dualismo sujeito-objeto, uma vez que não existe este dualismo na interpretação jurídica.

A relação sujeito-objeto, na interpretação jurídica, não é meramente contemplativa, onde a dogmática jurídica se apresenta como verdade absoluta, quase como verdade revelada.

Pelo contrário, essa relação é, sim, e antes de tudo, uma atividade subjetiva, onde o sujeito tem papel ativo.

\footnotetext{
As características dos textos normativos indicam que sua leitura oferece várias possibilidades de interpretação, fazendo com que o intérprete participe ativamente da elaboração da norma ao conferir sentido aos enunciados jurídicos. $\mathrm{O}$ reconhecimento de que a partir de um mesmo texto podem ser construídas diferentes normas significa que a norma não se confunde com o texto nem é um dado anterior à intervenção do intérprete, mas sim o resultado de um processo de interpretação, indispensável para a aplicação do direito (MAUÉS; FONSECA; REGO; 2010).
}

Mello e Pacheco (2010) citam excelente elucidação formulada por Stein, o qual defende que "o sentido não está no texto. O sentido será dado pelo intérprete. Não há um sentido a priori, que seja anterior e independente do respectivo contexto em que ele se insere". 
Segundo Folloni (2010) "pode-se entender, então, a norma jurídica não como o texto da lei, mas como a significação construída pelo intérprete. O intérprete não interpreta a norma; interpreta a lei e, como corolário, constrói a norma”.

O julgador não pode sucumbir, de maneira inconsciente, à força simbólica que as súmulas vinculantes representam, devendo superar a dogmática hermenêutica da dualidade sujeito-objeto.

Um nítido exemplo das conseqüências geradas pela aprovação, interpretação e aplicação de uma súmula vinculante pode ser constatado no que diz respeito à base de cálculo do adicional de insalubridade.

\section{A POLÊMICA JURISPRUDENCIAL SOBRE A BASE DE CÁLCULO DO ADICIONAL DE INSALUBRIDADE}

A parte final do disposto no inciso IV do artigo $7^{\circ}$ da Constituição Federal proíbe que o salário mínimo seja vinculado para qualquer fim.

Desse modo, milhares de pessoas, que percebiam adicional de insalubridade vinculado ao salário mínimo, ajuizaram ações alegando a inconstitucionalidade dessa vinculação, por afrontar a parte final do preceito acima citado.

Essas pessoas argumentavam que tinham direito a receber o adicional de insalubridade com base em sua própria remuneração, motivo pelo qual pediam o recebimento das respectivas diferenças salariais.

Todavia, o reconhecimento da citada inconstitucionalidade sempre gerou polêmica na jurisprudência.

Para alguns juízes a parte final do dispositivo em questão teria o escopo de evitar a indexação da economia.

Mas em que exatamente consiste essa indexação?

Alude ao fato de não se conceber que o aumento do salário mínimo provoque automaticamente a elevação dos preços de moradia, saúde, educação, lazer, transporte, higiene, o que coibiria e tornaria inviável e inútil o próprio aumento.

O objetivo da norma constitucional é o contrário, ou seja, que o valor do salário mínimo aumente sem o correspondente aumento dos preços de outros itens indispensáveis às necessidades vitais do empregado.

Desse modo, o poder aquisitivo do salário mínimo seria elevado ao longo dos anos, melhorando a qualidade de vida do trabalhador. 
Todavia, os defensores dessa teoria não admitem que a parte final do disposto no inciso IV do art. $7^{\circ}$, da $\mathrm{CF} / 88$, proíbe a vinculação do salário mínimo para outras situações.

Assim, a mencionada proibição serviria apenas para que o salário mínimo não servisse de indexador econômico, sendo legítima a sua utilização como base de cálculo do adicional de insalubridade ${ }^{5}$.

Esse era o entendimento adotado pela $2^{\mathrm{a}}$ Turma do $\mathrm{STF}^{6}$.

No entanto, outros juízes entendiam que a vinculação do salário mínimo para pagamento do adicional de insalubridade era flagrantemente inconstitucional ${ }^{7}$.

Esse era o entendimento da $1^{\text {a }}$ Turma do $\mathrm{STF}^{8}$.

Percebe-se, desse modo, que a interpretação do disposto na parte final do inciso IV do artigo $7^{\circ}$ da $\mathrm{CF} / 88$ causou evidente e enorme divergência jurisprudencial.

Para pacificar o entendimento sobre a matéria o STF resolveu editar a Súmula Vinculante n. 4.

\subsection{A APROVAÇÃO DA SÚMULA VINCULANTE N. 4}

Os policiais militares do Estado de São Paulo à época da aprovação da Súmula Vinculante n. 4 percebiam adicional de insalubridade com base na Lei Complementar estadual n. 432 , de 18.12 .85 .

A referida lei complementar vinculava o pagamento de adicional de insalubridade dos policiais militares ao salário mínimo9.

De acordo com os policiais militares, seria inconstitucional a incidência e a vinculação do salário mínimo para fins de pagamento do adicional de insalubridade, por notória afronta ao disposto na parte final do inciso IV, do art. $7^{\circ}$, da CF/88.

\footnotetext{
5 Nesse sentido, STF: RE 340.275, RE 458.802, AI 638.100-AgR, RE 230.688-AgR, AI 169.269-AgR, RE 230.528

${ }^{6}$ Recurso Extraordinário. Adicional de insalubridade. Vinculação ao salário mínimo. Art. $7^{\circ}$, IV, CF 88. 1. O art. $7^{\circ}$, IV da Constituição proíbe tão-somente o emprego do salário mínimo como indexador, sendo legítima a sua utilização como base de cálculo do adicional de insalubridade. 2. Precedentes. 3. Recurso extraordinário conhecido e improvido (RE 340.275, Rel. Elllen Gracie, DJ 22.10.04).

7 STF: RE 284.627, RE 329.336, RE 235.643, RE 197.072, RE 288.189, RE 247.656, RE 270.888-AgR.

8 Agravo Regimental em Recurso Extraordinário. Trabalhista. Adicional de insalubridade. Vinculação ao salário mínimo. Inconstitucionalidade. A utilização do salário mínimo como base de cálculo do adicional de insalubridade ofende a parte final do inciso IV do artigo $7^{\circ}$ da Constituição Federal. Precedentes: RE 435.011AgR e AI 423.622-ED. Agravo Regimental desprovido (RE 451.220 AgR, Rel. Carlos Britto, DJ 20.04.06).

${ }^{9}$ Art. $3^{\circ} \mathrm{O}$ adicional de insalubridade será pago ao funcionário ou servidor de acordo com a classificação nos graus máximo, médio e mínimo, em percentuais de, respectivamente, $40 \%$ (quarenta por cento), $20 \%$ (vinte por cento) e $10 \%$ (dez por cento), que incidirão sobre o valor correspondente a 2 (dois) salários mínimos.

$\S 1^{\circ}$ - O valor do adicional de que trata este artigo será reajustado sempre que ocorrer a alteração no valor do salário mínimo.

$\S 2^{\circ}$ - Vetado.
} 
Por esse motivo, os policiais entendiam que tinham o direito a receber o adicional de insalubridade com base em sua remuneração.

Assim sendo, eles ajuizaram diversas ações pelas quais pleitearam o recebimento de diferenças salariais.

A questão chegou ao STF por meio do RE n. 565714, este interposto pelos aludidos policiais militares.

A relatora do recurso foi a Ministra Cármen Lúcia, que teceu brilhante voto ${ }^{10}$.

Para a Ministra Cármen Lúcia a parte final do disposto no inciso IV do art. $7^{\circ}$ da CF/88 proíbe que o salário mínimo sirva de indexador não só econômico, como de qualquer outro índice, inclusive de parcelas salariais.

O aumento no valor do salário mínimo seria prejudicado pelo receio do efeito cascata que dele pudesse advir.

Dito de outro modo, o Poder Executivo não iria aumentar o valor do salário mínimo com receio de que o seu ato pudesse provocar um impacto na economia, através do aumento do salário de milhares de pessoas, estas com salário ou adicionais salariais vinculados àquele.

Apenas em algumas situações, excepcionadas pela própria $\mathrm{CF} / 88$, seria legal a vinculação do salário mínimo.

Essas situações excepcionais seriam, por exemplo, a fixação da pensão dos seringueiros em dois salários-mínimos (art. 54 do ADCT), a conversão dos benefícios previdenciários em número de salários-mínimos para a preservação de seu poder aquisitivo (art. 58 do ADCT), a vinculação do pagamento do PIS e PASEP ao trabalhador que ganha até dois salários-mínimos (art. 239, parágrafo $3^{\circ}$ ), a definição em números de salários mínimos

10 “O sentido [da] vedação constante da parte final do artigo $7^{\circ}, \mathrm{IV}$, da Constituição [...], [é o de evitar que o salário-mínimo] seja usado como fato de indexação, para que, com essa utilização, não se crie empecilho ao aumento dele em face da cadeia de aumentos que daí decorrerão se admitida essa vinculação, tal como bem lançado pelo eminente Ministro Moreira Alves no Recurso Extraordinário n. 217.700.

A norma teve como um de seus objetivos impedir que os aumentos do salário-mínimo gerem, indiretamente, um peso maior do que aquele diretamente relacionado com esses aumentos, circunstância que pressionaria para um reajuste menor do salário-mínimo, o que significaria obstaculizar a implementação da política salarial prevista no mesmo art. $7^{\circ}$, inciso IV, da Constituição da República.

Pode-se dizer que é um dispositivo completo, pois além de determinar os objetivos a serem alcançados pelo salário-mínimo (capaz de atender às [...] necessidades vitais básicas [do trabalhador e] de sua família com moradia, alimentação, educação, saúde, lazer, vestuário, higiene, transporte e previdência social), cria o mecanismo obrigatório para atingi-los e evitar o retrocesso nas conquistas (reajustes periódicos que lhe preservem o poder aquisitivo), proibindo-se a prática de um dos obstáculos que impedem ou dificultam as suas concretizações (vedada sua vinculação para qualquer fim).

Não vislumbro dúvida razoável de que a utilização do salário-mínimo para a formação da base de cálculo de qualquer parcela remuneratória ou com qualquer outro objetivo pecuniário (indenizações, pensões, etc) incide na vinculação vedada pela Constituição do Brasil. O que é ali proibido é exatamente tomar-se o salário mínimo como fator indexador para novos e diferenciados ganhos decorrentes ou não de dever remuneratório". 
para a obrigação que deve ser saldada pelo Poder Público sem expedição de precatórios (art. 84 ADCT), entre outros.

Os argumentos suscitados pela Ministra Cármen Lúcia procedem?

Não se sabe até que ponto a vinculação do salário mínimo para pagamento de adicional de insalubridade de empregado celetista prejudicaria diretamente o poder aquisitivo do próprio salário mínimo.

A simples vinculação do salário mínimo como base de cálculo para o pagamento do adicional de insalubridade, sem afetar outros índices de preços, tais como combustíveis, aluguéis, entre outros, não provocaria diretamente uma diminuição do seu poder aquisitivo.

Pelo contrário, se o salário mínimo provocasse apenas o aumento do valor do adicional de insalubridade do empregado e, se os demais preços permanecessem estáveis, obviamente haveria benefícios.

Neste caso verificar-se-ia um aumento real do poder aquisitivo do salário mínimo.

De outra banda, com relação aos servidores públicos, a Carta de 1988 possui outros preceitos, além do disposto no inciso IV do seu art. $7^{\circ}$, que proíbe a vinculação do salário mínimo para fins de pagamento de adicional de insalubridade.

A Constituição Federal dispõe em seu em seu art. 18 que "a organização políticoadministrativa da República Federativa do Brasil compreende a União, os Estados, o Distrito Federal e os Municípios, todos autônomos, nos termos desta Constituição".

Segundo Bulos (2000, p. 448), a mensagem que se extrai do art. 18 da CF/88 é a seguinte: "a União, os Estados, o Distrito Federal e os Municípios são entidades autônomas, consignando elementos formadores do Estado federal brasileiro".

Firmou-se a jurisprudência do STF no sentido de que a lei não pode autorizar reajustes automáticos de vencimentos de servidores públicos dos Estados e dos Municípios, vinculando-os às variações de determinados índices ditados pelo Governo Federal.

Entendeu-se, nas várias ocasiões em que o tema foi enfrentado, que o critério viola, sobretudo, o princípio irremovível da autonomia estadual e municipal prevista no caput do art. 18 da Constituição Federal.

Isto porque a remuneração dos servidores estaduais e municipais acabaria automaticamente reajustada por efeito de ato do Governo Federal ${ }^{11}$.

\footnotetext{
${ }^{11}$ Recurso extraordinário. Gatilho salarial. Artigo 25 e seu parágrafo único da Lei Complementar n. 467, de 02.07.86, do Estado de São Paulo. - A atual jurisprudência firmada pelo Plenário desta Corte - assim, entre outros julgados, os prolatados nas ações originárias 286, 299 e 300 -, ao julgar casos análogos ao presente em que a lei estadual determinava o automático reajuste da remuneração do servidor público, a título de antecipação salarial, pela variação do IPC, ou seu equivalente, toda vez que tal remuneração atingisse $20 \%$, decidiu pela
} 
Trata-se de questão que foi pacificada pelo Supremo Tribunal Federal, especificamente através da Súmula 681, que estabelece ser "inconstitucional a vinculação de reajuste de vencimentos de servidores estaduais ou municipais a índices federais de correção monetária”.

O salário mínimo é fixado por ato do governo federal, logo, não se pode fixar em leis municipais ou estaduais o pagamento de adicional de insalubridade de servidor público vinculado ao salário mínimo, sob pena de o ato federal ferir o caput do art. 18 da Lei Maior.

Por outro lado, a EC 19/98 deu nova redação ao inciso XIII, do art. 37 da Lei Maior estabelecendo que "é vedada a vinculação ou equiparação de quaisquer espécies remuneratórias para o efeito de remuneração de pessoal do serviço público".

A norma em comento teria o propósito de proibir "o tratamento jurídico paralelo de cargos com funções desiguais (equiparação) e a subordinação de um cargo a outro, dentro ou fora do mesmo Poder, (...)”, Meirelles (2000, p. 418).

Além disso, o preceito pretende impedir o reajuste automático de vincimentos, o que “ocorreria se os reajustes de salários ficassem vinculados a determinados índices, como o de aumento do salário mínimo, o de aumento da arrecadação, o de títulos da dívida pública ou qualquer outro", Di Pietro (2000, p. 430).

Mesmo antes da EC n. 19/98 o Órgão Especial do Tribunal de Justiça do Estado de São Paulo manifestava-se a respeito dessa questão, adotando orientação idêntica.

Para o citado Órgão era inadmissível a vinculação a qualquer índice ou valor automático ou predeterminado, pois a vedação constitucional não se limita ao paralelismo de carreiras, cargos ou funções ${ }^{12}$.

Desse modo, com relação aos servidores públicos, a vinculação do salário mínimo é inconstitucional também por afronta ao que dispõe o inciso XIII do art. 37 da Lei Maior.

\footnotetext{
inconstitucionalidade dessa norma inclusive por atentar contra a proibição da vinculação de qualquer natureza para o efeito de remuneração do pessoal do serviço público ao conceder reajuste automático a índice de correção monetária fixado pela União. - É o que ocorre no caso, em que o artigo 25 e seu parágrafo único da Lei Complementar n. 467, de 02.07.86, do Estado de São Paulo estabelecem: Art. 25 Os vencimentos, remuneração, proventos e pensões serão reajustados automaticamente pela variação acumulada do Índice de Preços ao Consumidor - IPC, sempre que a acumulação atingir 20\% (vinte por cento). Parágrafo único. O reajuste concedido nos termos deste artigo será considerado antecipação salarial”. - Da orientação desta Corte divergiu o acórdão recorrido. Recurso extraordinário conhecido e provido, declarando-se a inconstitucionalidade do artigo 25 e seu parágrafo único da Lei complementar n. 467, de 02.07.86, do Estado de São Paulo (RE 174184. Rel. Min. MOREIRA ALVES. Julgamento 02.08.2001. Órgão Julgador: Tribunal Pleno. Publicação: DJ data 21.09.2001. p.p. 00054. EMENT VOL-02044-02 PP-00332).

${ }^{12}$ Confira, TJSP: RIN n. 18.908-0, Rel. Dês. Ney Almada, j. 21.9.94; ADI n. 19.776-0, SP, Rel. Des. Renan Lotufo, j. 24.8.94; RIN n. 11.250-0, SP., Rel. Des. Carlos Ortiz, j. 28.3.90.
} 
E não é só. Para os servidores públicos outras limitações para o reajuste automático de vencimentos estão contidas nos incisos I e II, do $\S 1^{\circ}$, do art. 169 da CF/88.

Uma dessas limitações consiste no fato de que a concessão de qualquer vantagem ou aumento de remuneração de servidor público só pode ser feita se houver prévia dotação orçamentária suficiente para atender às projeções de despesa de pessoal e aos acréscimos dela decorrentes.

Além disso, o aumento de remuneração de servidor público é limitado pela necessidade de previsão específica na lei de diretrizes orçamentárias.

Por fim, a parte final do disposto no inciso IV do art. $7^{\circ}$ da Carta Magna estabelece o termo: "sendo vedada sua vinculação para qualquer fim".

Se o Poder Constituinte não possibilitou qualquer tipo de vinculação, por óbvio não compete ao intérprete fazê-lo.

Estas razões evidenciam a inconstitucionalidade da vinculação do salário mínimo para pagamento de adicional de insalubridade de servidor público.

Nesse passo, no RE n. 565.714, a Ministra Cármen Lúcia decidiu em seu voto que a expressão "salários mínimos" contida na parte final do art. 3º da Lei n. 432/1985 e o $\S 1^{\circ}$ daquele artigo não foram recepcionados pelo art. $7^{\circ}$, inciso IV, da Lei Maior.

Em verdade, no RE n. 565.714, o STF decidiu que o salário mínimo não pode ser base para incidência de percentagem visando satisfazer adicional de insalubridade, nem, tampouco, servir de fator de indexação dessa parcela remuneratória. Como seria, então, calculada a base de cálculo para pagamento do adicional de insalubridade?

Antes de abordar essa questão, em seu voto a Ministra Cármen Lúcia comenta a vinculação do salário mínimo para pagamento de adicional de insalubridade nas relações trabalhistas.

\subsection{OS CELETISTAS}

Ao reconhecer a repercussão geral do RE 565714 a Ministra Cármen Lúcia salienta que a matéria envolve, também, os celetistas, motivo pelo qual, em seu voto, ela analisa a questão da vinculação do salário mínimo para pagamento do adicional de insalubridade nas relações trabalhistas.

A Ministra Cármen Lúcia decide que a matéria, com relação aos celetistas, é regida pela Consolidação das Leis do Trabalho. 
Segundo a Ministra Cármen Lúcia, o sentido da expressão "salário mínimo da região" contido no artigo 192 da CLT, não pode ser interpretado de modo a corresponder ao salário mínimo nacional, motivo pelo qual caberá à Justiça Trabalhista definir a base de cálculo do adicional de insalubridade.

\subsection{OS POLICIAIS MILITARES DO ESTADO DE SÃO PAULO}

$\mathrm{O}$ art. $7^{\circ}$, inciso XXIII, da CF/88 dispõe que são direitos dos trabalhadores "adicional de remuneração para as atividades penosas, insalubres ou perigosas, na forma da lei”.

Em seu voto a Ministra Cármen Lúcia afirma que o inciso XXIII do art. $7^{\circ}$ da $\mathrm{CF} / 88$ não se aplica aos policiais militares porque não consta no rol dos direitos previstos no $\S 3^{\circ}$ do art. 39 da Lei Maior. Para a Ministra Cármen Lúcia o próprio $§ 3^{\circ}$ do art. 39 da CF/88 não se aplica aos policiais militares.

No entanto, os militares, no RE n. 565.714, consignaram que o art. 124 , $\S 3^{\circ}$ da Constituição Paulista, incluía o inciso XXIII do art. $7^{\circ}$ da CF/88 como direito a eles aplicável.

Ainda assim, segundo a Ministra Cármen Lúcia se o inciso XXIII do art. $7^{\circ}$ da Lei Maior desejasse estabelecer a remuneração do trabalhador como base de cálculo teria afirmado adicional sobre a remuneração, o que não aconteceu.

Assim sendo, para a Ministra Cármen Lúcia o inciso XXIII do art. $7^{\circ}$ da $\mathrm{CF} / 88$ não define base de cálculo do adicional de insalubridade dos policiais militares.

Posteriormente, em seu voto a Ministra Cármen Lúcia demonstra uma ausência de parâmetro expresso na $\mathrm{CF} / 88$ para determinar a base de cálculo do adicional de insalubridade dos policiais militares.

Acontece que, para a Ministra Cármen Lúcia, o reconhecimento de inconstitucionalidade da vinculação do salário mínimo para pagamento do adicional de insalubridade, sem que houvesse a estipulação de outra base de cálculo, faria desaparecer o direito ao recebimento do próprio adicional de insalubridade.

Tal situação seria mais maléfica, caracterizando um retrocesso ao agravar a situação dos policiais militares que possuíam o direito ao recebimento do adicional de insalubridade antes do ajuizamento da ação que ensejou o RE n. 565.714.

No julgamento, após as ponderações feitas pela Ministra Cármen Lúcia, a matéria foi colocada em discussão pelo plenário do Supremo Tribunal Federal.

Os Ministros, então, adotaram a técnica de declaração de inconstitucionalidade, sem pronúncia de nulidade (da lei complementar paulista, art. $3^{\circ}$, caput, e $\S 1^{\circ}$ ). 
Segundo Mendes (2010), "trata-se daqueles casos em que a aplicação da lei mostra-se, do prisma constitucional, indispensável no período de transição, até a promulgação de nova lei”.

Desse modo, o STF considerou inconstitucional a vinculação do salário mínimo para o pagamento do adicional de insalubridade. Todavia, para os Ministros enquanto o legislador não editar lei que institua nova base de cálculo em substituição ao salário mínimo, este continuará sendo aplicado, permanecendo válida a lei complementar paulista.

Assim, foi aprovada a súmula vinculante n. 4, publicada no Diário Oficial da União, no dia 09.05.2008, com a seguinte redação: "Salvo nos casos previstos na Constituição, o salário mínimo não pode ser usado como indexador de base de cálculo de vantagem de servidor público ou de empregado, nem ser substituído por decisão judicial”.

A Súmula Vinculante n. 4 pacificou a divergência no que se refere à base de cálculo para o pagamento de adicional de insalubridade? Quais foram seus efeitos?

\section{A REPERCUSSÃO GERADA PELA SÚMULA VINCULANTE N. 4 NO DIREITO DO TRABALHO}

\subsection{A RECLAMAÇÃO N. 6266}

$\mathrm{O}$ art. 192 da CLT $^{13}$ prevê que o empregado tem direito a receber um adicional quando prestar serviços em condições insalubres, acima dos limites de tolerância estabelecidos pelo Ministério do Trabalho.

Para Roeder Filho (2010) o adicional de insalubridade possui caráter nitidamente salarial, "pois visa remunerar o empregado pelos riscos ou desgaste vivenciados em seu labor, sendo, portanto, o próprio empregado compensado pelo exercício do labor em condições nocivas à sua saúde".

O mesmo art. 192 da CLT prevê que o referido adicional será calculado à razão de 10\% (grau mínimo), 20\% (grau médio) e 40\% (grau máximo), incidente sobre o salário mínimo da região.

Antes da aprovação e publicação da súmula vinculante $\mathrm{n} .4$ prevalecia no TST o entendimento consolidado no sentido de que o adicional de insalubridade, devido a

\footnotetext{
${ }^{13}$ Dispõe o artigo 192 da CLT: "O exercício de trabalho em condições insalubres, acima dos limites de tolerância estabelecidos pelo Ministério do Trabalho, assegura a percepção de adicional respectivamente de $40 \%$ (quarenta por cento), $20 \%$ (vinte por cento) e 10\% (dez por cento) do salário mínimo da região, segundo se classifiquem nos graus máximo, médio e mínimo".
} 
empregado, seria calculado sobre o salário mínimo, salvo se houvesse norma mais benéfica prevista em convenção coletiva ou sentença normativa ${ }^{14}$.

Após a aprovação da súmula vinculante n. 4, a Sétima Turma do TST passou a adotar o entendimento no sentido de ser vedado ao Poder Judiciário substituir o salário mínimo por outro índice para fins de pagamento de adicional de insalubridade ${ }^{15}$ :

No entanto, no dia 26.06.2008, ao apreciar a matéria, o plenário do TST decidiu de maneira diversa.

O Pleno do TST entendeu que, na ausência de fixação de base de cálculo para o pagamento do adicional de insalubridade em instrumento coletivo, tal pagamento deveria ser feito tendo-se em vista o valor do salário básico.

Foi assim que o C. TST deu nova redação para a súmula n. 228 estabelecendo que, a partir de 9 de maio de 2008, data da publicação da súmula vinculante n. ${ }^{\circ}$ 4, o adicional de

\footnotetext{
${ }^{14}$ Enunciado $\mathrm{n}^{\mathrm{o}} 17$ - O adicional de insalubridade devido a empregado que, por força de lei, convenção coletiva ou sentença normativa, percebe salário profissional será sobre este calculado.

Enunciado $\mathrm{n}^{\circ}$ 228: O percentual do adicional de insalubridade incide sobre o salário mínimo de que cogita o art. 76 da CLT, salvo as hipóteses previstas na Súmula 17.

Orientação Jurisprudencial $n^{0} 2$ da SBDI-1. Adicional de insalubridade. Base de cálculo. Mesmo na vigência da CF/88: salário mínimo.

${ }^{15}$ EMENTA: ADICIONAL DE INSALUBRIDADE - BASE DE CÁLCULO - SALÁRIO MÍNIMO (CLT, ART. 192) - DECLARAÇÃO DE INCONSTITUCIONALIDADE SEM PRONÚNCIA DE NULIDADE (UNVEREINBARKEITSERKLÄRUNG-) - SÚMULA 228 DO TST E SÚMULA VINCULANTE 4 DO STF. 1. O STF, ao apreciar o RE-565.714-SP, sob o pálio da repercussão geral da questão constitucional referente à base de cálculo do adicional de insalubridade, editou a Súmula Vinculante 4, reconhecendo a inconstitucionalidade da utilização do salário mínimo, mas vedando a substituição desse parâmetro por decisão judicial. Rejeitou, inclusive, a tese da conversão do salário mínimo em sua expressão monetária e aplicação posterior dos índices de correção dos salários, uma vez que, sendo o reajuste do salário mínimo mais elevado do que a inflação do período, restariam os servidores e empregados postulantes de uma base de cálculo mais ampla prejudicados ao receberem como prestação jurisdicional a redução da vantagem postulada. 2 . Assim decidindo, a Suprema Corte adotou técnica decisória conhecida no Direito Constitucional Alemão como declaração de inconstitucionalidade sem pronúncia da nulidade (-Unvereinbarkeitserklärung-), ou seja, a norma, não obstante ser declarada inconstitucional, continua a reger as relações obrigacionais, em face da impossibilidade de o Poder Judiciário se substituir ao legislador para definir critério diverso para a regulação da matéria. 3. O Direito Constitucional pátrio encampou tal técnica no art. 27 da Lei 9.868/99, o qual dispõe que, -ao declarar a inconstitucionalidade de lei ou ato normativo e tendo em vista razões de segurança jurídica ou de excepcional interesse social, poderá o Supremo Tribunal Federal, por maioria de dois terços de seus membros, restringir os efeitos daquela declaração ou decidir que ela só tenha eficácia a partir de seu trânsito em julgado ou de outro momento que venha a ser fixado-. -In casu-, o momento oportuno fixado pela Suprema Corte foi o da edição de norma que substitua a declarada inconstitucional. 4. Nesse contexto, ainda que reconhecida a inconstitucionalidade do art. 192 da CLT e, por conseguinte, da própria Súmula 228 do TST, tem-se que a parte final da Súmula Vinculante 4 do STF não permite criar critério novo por decisão judicial, razão pela qual, até que se edite norma legal ou convencional estabelecendo base de cálculo distinta do salário mínimo para o adicional de insalubridade, continuará a ser aplicado esse critério para o cálculo do referido adicional, salvo a hipótese da Súmula 17 do TST, que prevê como base de cálculo o piso salarial da categoria que o possua (já que o piso salarial é o salário mínimo da categoria). [...] - (Processo: ED-RR - 70800-03.2004.5.17.0006. Data de Julgamento: 11.06.2008, Relator Ministro Ives Gandra Martins Filho, $7^{\text {a }}$ Turma, data de publicação: 05.09.2008).
} 
insalubridade seria calculado sobre o salário básico, salvo critério mais vantajoso previsto em instrumento coletivo ${ }^{16}$.

Acontece que, após ser publicada a nova redação da Súmula 228 do TST, a Confederação Nacional da Indústria (CNI) ajuizou Reclamação junto ao Excelso Supremo Tribunal Federal, feito que foi autuado sob o n. 6.266.

Na aludida Reclamação n. 6.266, no dia 15.07.2008, o Ministro presidente do STF Gilmar Mendes deferiu a liminar então pleiteada pela CNI, de tal sorte que a súmula 228 do TST foi suspensa na parte em que permitia a utilização do salário básico com parâmetro para se calcular o valor do adicional de insalubridade.

Por outro lado, ao deferir o ingresso de $\operatorname{terceiros}^{17}$ na citada Reclamação 6.266, a relatora do processo, Ministra Cármen Lúcia, salientou que o presidente do TST havia prestado informações afirmando que o escopo da Súmula 228 era exatamente uniformizar o entendimento dos Tribunais trabalhistas sobre a matéria.

Essa decisão foi proferida pela Ministra Carmem Lúcia no dia $14.10 .2008^{18}$, sendo este o último andamento do processo até a presente data.

A decisão liminar da Reclamação 6.266 fez com que o TST mudasse sua orientação sobre a matéria, de tal sorte que o salário mínimo voltou a servir como base de cálculo para pagamento de adicional de insalubridade, até que seja aprovada lei que institua novo índice ${ }^{19}$.

\footnotetext{
${ }^{16}$ ADICIONAL DE INSALUBRIDADE. BASE DE CÁLCULO. A partir de 9 de maio de 2008, data da publicação da Súmula Vinculante $\mathrm{n}^{\circ} 4$ do Supremo Tribunal Federal, o adicional de insalubridade será calculado sobre o salário básico, salvo critério mais vantajoso fixado em instrumento coletivo (publicada em 04/07/08).

${ }^{17}$ Confederação Nacional dos Trabalhadores da Indústria Química - CNTQ; Confederação Nacional dos Trabalhadores Metalúrgicos - CNTN; Central dos Trabalhadores e das Trabalhadoras do Brasil - CTB; Sindicado dos Trabalhadores nas Indústrias Metalúrgicas, Mecânicas e de Material Elétrico de Caixias do Sul.

${ }^{18}$ DJE: 04.11.2008.

${ }^{19}$ EMBARGOS - ADICIONAL DE INSALUBRIDADE - BASE DE CÁLCULO - SÚMULA VINCULANTE $\mathrm{N}^{\circ} 4$ DO STF - INAPLICABILIDADE DO SALÁRIO PROFISSIONAL OU PISO SALARIAL 1. O E. Supremo Tribunal Federal, por meio da Súmula Vinculante $n^{\circ} 4$, publicada em 9/5/2008, entendeu que, por um lado, a Constituição vedou o uso do salário mínimo como base de cálculo e, por outro, não elegeu o salário ou a remuneração do trabalhador para esta função. 2. Conforme se extrai da transcrição dos debates ocorridos na sessão de julgamento do precedente que levou o E. STF a editar a aludida súmula vinculante, tem-se que esta deixa a resolução sob responsabilidade do Legislativo ou das partes coletivas, preservando, até a edição de norma específica ou convenção coletiva de trabalho, a base de cálculo historicamente utilizada. 3. Assim, o adicional de insalubridade, enquanto perdurar o vácuo legislativo em questão, deve ser pago nos moldes em que historicamente o foi, conforme entendimento consagrado na Súmula no 228 do TST, em sua antiga redação, já que não cabe ao Poder Judiciário fixar base de cálculo diversa da prevista em lei. 4 . A Súmula $n^{\circ} 17$ do TST, por sua vez, que consagrava a adoção do salário profissional ou piso salarial como base de cálculo do adicional de insalubridade, foi cancelada pela Resolução no 148/2008, pois contrária à referida súmula vinculante. 5. Em recente decisão (Rcl-7579/DF-MC, publicada no DJe de 18/2/2009), o Excelso STF também reconheceu contrariedade à aludida súmula vinculante, na hipótese de adoção do salário profissional como base de cálculo do adicional de insalubridade. Embargos conhecidos e desprovidos. (Processo: E-RR - 19720012.2004.5.12.0003 Data de Julgamento: 30.11.2009, Relatora Ministra: Maria Cristina Irigoyen Peduzzi, Subseção I Especializada em Dissídios Individuais, Data de Divulgação: DEJT 11.12.2009).
} 
As decisões, todavia, não dirimiram totalmente a questão sobre a base de cálculo para pagamento de adicional de insalubridade.

Alguns defendem que o pagamento do adicional de insalubridade não pode ser vinculado à remuneração do obreiro porque o propósito do STF, ao editar a súmula vinculante n. 4, teria sido evitar um passivo trabalhista:

\begin{abstract}
O Supremo Tribunal Federal, ao declarar a inconstitucionalidade do art. 192 da CLT sem pronúncia de nulidade, teve o intento de harmonizar os interesses da coletividade e dos indivíduos em sim mesmo considerados, pois, ao mesmo tempo em que preserva a situação dos trabalhadores, evitando com isso o retrocesso social, já que a retirada dos dispositivos inconstitucionais seria mais prejudicial, impede que a base legal seja substituída por decisão judicial, com o propósito de não provocar um aumento no passivo trabalhista (LIMA, 2010).
\end{abstract}

No entanto, para Nascimento (2010) "diante da inexistência de norma legal específica para a base de cálculo do adicional de insalubridade, aplica-se, então, por analogia o disposto no parágrafo $1^{\circ}$, do art. 193 da CLT",20.

Seguindo tal linha de pensamento, o adicional de insalubridade passaria a incidir sobre o salário contratual, pago por mês, sem os acréscimos resultantes de gratificações, prêmios ou participações nos lucros da empresa.

Existem, ainda, aqueles que sinalizam no sentido de que deveria ser atribuído um determinado valor para base de cálculo do adicional de insalubridade, que, posteriormente, seria corrigido monetariamente:

Como reflexo da edição da quarta súmula vinculante, e do cenário atual, mostra-se em conformidade com suas disposições a conversão do adicional de insalubridade para a unidade monetária nacional ( $\mathrm{R}$ - reais), considerando o valor do salário mínimo à época da edição da súmula vinculante, aplicando-se sobre o resultado da conversão os futuros reajustes salariais convencionados, ou seja, atualizando-o monetariamente, não havendo norma legal que obrigue o empregador a observar o novo valor do salário mínimo a ser fixado (LEMOS, 2010).

A situação, portanto, encontra-se indefinida, estando aguardando a decisão final a ser proferida em sede da Reclamação n. ${ }^{\circ} 6266$.

\title{
3.2 O MANDADO DE INJUNÇÃO E A SÚMULA VINCULANTE N. 4
}

\footnotetext{
${ }^{20}$ Art. 193. (...) $\S 1^{\circ}$ - O trabalho em condições de periculosidade assegura ao empregado um adicional de $30 \%$ sobre o salário sem os acréscimos resultantes de gratificações, prêmios ou participações nos locais da empresa.
} 
Gemignani (2010) defende a total independência entre o verbete da súmula vinculante n. ${ }^{\circ} 4$ e as peculiaridades do RE 565714, pois, segundo ela, as razões de decidir contidas no citado recurso não fazem parte da súmula, atuando tão somente como "questão periférica".

De modo que a súmula vinculante n. 4 não guardaria qualquer vinculo de origem com os fundamentos que lhe deram origem, estes suscitado em sede do RE n. 565.714.

Um pouco ao contrário do que se propõe, entendemos que a aplicação da tese da total independência entre o caso que gerou a súmula vinculante n. 4 e seu enunciado não pode ser radicalizada, aplicando-a indistintamente.

A tese deve ser aplicada de maneira equilibrada, de forma teleológica.

É óbvio que a Súmula Vinculante n. 4 aplica-se a todos os policiais militares do Estado de São Paulo, mas daí a aplicá-la para todos os casos, inclusive com situações diferentes, seria um erro.

A súmula vinculante não é uma lei.

A súmula vinculante é o produto da interpretação de vários casos similares sob um mesmo tema.

De modo que as peculiaridades do caso de repercussão geral que deu origem à súmula vinculante n. 4 deve, sim, servir de parâmetro para balizar e distinguir a aplicação da súmula para um caso diferente.

Aliás, no common law não se pretende sintetizar a ratio decidendi do caso de modo a ser formulada uma súmula para aplicação em todos os casos.

Assim, a ratio decidendi, do common law, não seria, no caso presente, apenas o que está contido no enunciado da súmula vinculante n. 4 , e, sim, as razões pelas quais o STF determinou que a proibição deve ser observada, e em que casos.

Toda a fundamentação do RE n. 565.714 (incluindo a não recepção da lei complementar paulista, a manutenção do poder aquisitivo do salário mínimo) seria a ratio decidendi, não somente o verbete da súmula vinculante n. 4 .

Se fossemos desvirtuar a ratio decidendi do common law de tal sorte a entendê-la apenas como o enunciado contido na súmula vinculante n. 4 , surgiria outro problema.

Na hipótese, a ratio decidendi também seria composta pelo que dispõe a parte final da súmula vinculante n. 4, que proíbe o Poder Judiciário de substituir o salário mínimo por outro índice para fins de pagamento de adicional de insalubridade. 
Assim, a aplicação da tese da total independência entre o caso que originou a súmula e o enunciado desta última, sem qualquer ressalva, ao invés de permitir entendimentos diferentes, cercearia o magistrado de qualquer interpretação.

O juiz, diante de um caso concreto, em síntese, não poderia, como no common law, demonstrar que as razões do caso que originou a súmula vinculante n. 4 não coincidem com as razões do caso posto em julgamento.

Desse modo, pela obediência à tese consistente na total desvinculação entre o caso que gerou a súmula vinculante n. 4 e seu enunciado, o juiz seria obrigado a continuar aplicando o salário mínimo para fins de pagamento de adicional de insalubridade.

A rigor essa decisão deveria ser proferida em todos os casos relativos à matéria em questão, não sendo possível qualquer outra interpretação, o que não deve prevalecer.

De outra banda, o corte do "cordão umbilical" entre o caso que gerou a súmula vinculante n. 4 e seu enunciado não faz nascer ao juiz o direito de decidir de forma aleatória.

Ao juiz não é permitido simplesmente opinar por qual teria sido a "vontade do STF", se essa ou aquela, expressa no verbete da mencionada súmula vinculante n. 4 .

A tese em comento, consistente no desligamento da ratio decidendi do RE n. 565.714 e o enunciado da súmula vinculante n. 4 não possibilita a que o juiz, diante de um caso concreto, fundamente sua decisão suscitando outras eventuais vontades do STF.

Não é porque não se aplica no Brasil a técnica das distinções das decisões do sistema common law, que o juiz pode ficar livre para justificar sua decisão concreta em outras eventuais vontades do STF.

Assim, é incorreto dizer que a súmula vinculante pretendeu preservar a saúde do trabalhador, ou, por exemplo, diminuir gastos com previdência.

O que pode ser afirmado, com certeza, é que as súmulas vinculantes não retiraram do julgador sua principal função, que é, em ultima análise, dizer o direito.

É nesse sentido que a questão deve ser analisada, ou seja, ainda que se entender as súmulas vinculantes como conceitos abstratos, sem qualquer vínculo de origem, mesmo assim subsiste o poder/dever do juiz de interpretá-las.

Todavia, ao juiz é imposto o dever de julgar, mas não ao seu bel prazer, e sim por meio de regras postas e ditadas pelo conjunto de todo o ordenamento jurídico.

A Constituição Federal estabelece em seu art. $5^{\circ}$, inciso XXXV, que a "lei não excluirá da apreciação do Poder Judiciário lesão ou ameaça a direito”.

Trata-se de um direito fundamental, uma cláusula pétrea. 
Tendo em vista o monopólio do Poder Judiciário sobre a jurisdição, o termo "lei" previsto no art. $5^{\circ}$, inciso XXXV da Carta Magna, deve ser interpretado de forma ampla.

Assim, um ato administrativo, um decreto, uma portaria, uma súmula vinculante, enfim, não poder haver uma norma geral e abstrata, que, aplicada coercitivamente, exclua da apreciação, pelo Poder Judiciário, de lesão a direito.

Mas, qual direito?

No caso, o direito infraconstitucional de o jurisdicionado ver o juiz julgar o caso, sendo a lei omissa, usando a analogia, os costumes e os princípios gerais do direito, nos termos do disposto no art. $4^{\circ}$ da Lei de Introdução ao Código Civil.

O salário mínimo foi instituído no Brasil pela Lei $n^{\circ}$ 185, de 14 de janeiro de 1936, mas os níveis salariais mínimos foram fixados pela primeira vez pelo Decreto-lei $\mathrm{n}^{\circ} 2.162$, de $1^{\circ}$ de maio de 1940.

Esses níveis eram bastante variados, de acordo com as diferentes regiões (isto é, os Estados), oscilando entre o menor, de 120 mil réis (Maranhão e Piauí), e o máximo, de 240 mil réis (Distrito Federal, hoje município do Rio de Janeiro, então Capital da República).

O salário mínimo era fixado de acordo com diversas regiões. Neste sentido, dispunha o art. 76 da Consolidação das Leis do Trabalho, mediante preceito que inspirou o art. 157, I, da Constituição de 1946, que também alude a "regiões" (condições de cada região).

A referência a "regiões" foi mantida pelas subseqüentes constituições.

Entretanto, a Carta vigente, de 1988, em seu artigo $7^{\circ}$, inciso IV, determinou fosse o salário mínimo "nacionalmente unificado".

Pela derrogação parcial do artigo 192 da CLT o TST passou a utilizar o salário mínimo nacional para fins de pagamento do adicional de insalubridade, tema objeto da súmula 228 , em sua primeira redação.

A súmula vinculante n. $^{\circ} 4$, por sua vez, manteve o valor do salário mínimo nacional como base de cálculo para pagamento do adicional de insalubridade, até a edição de outro índice, por meio de lei.

Analisando-se a súmula vinculante n. $^{\circ} 4$ como um tema estigmatizado, o interprete não teria qualquer dificuldade em manter a aplicação da súmula 228, até edição de lei que viesse a regulamentar o valor do adicional de insalubridade.

A questão, todavia, não é tão simples quanto parece.

Como registrado ao longo deste trabalho, uma correta interpretação das súmulas vinculantes só ocorre quando se analisa especificamente as razões que lhe deram origem. 
Nesse sentido, observando-se detidamente o inteiro teor, a ratio decidendi, da decisão proferida no RE 565714, percebe-se que, de fato, houve reconhecimento expresso da inconstitucionalidade da vinculação do salário mínimo para fins de pagamento do adicional de insalubridade.

Cabe ressaltar, no RE 565.714, discutia-se uma lei complementar, que dispunha sobre base de cálculo de adicional de insalubridade de policiais militares, servidores públicos.

Conforme já demonstrado neste trabalho, os incisos I e II, do $\S 1^{\circ}$, do artigo 169 , da Constituição Federal, exigem prévia dotação orçamentária e autorização específica em lei, para aumento de remuneração dos servidores públicos.

Pelas exigências legais, era proibida a aplicação da analogia como argumento para substituir a base de cálculo do adicional de insalubridade dos policiais.

Se não bastasse, a Lei Maior também impede a aplicação da isonomia como fundamento para aumento de remuneração dos servidores públicos, pois o Poder Judiciário não tem função legislativa, tema que foi pacificado pelo STF através da súmula $339^{21}$.

Foi por essas razões que, embora tenha reconhecido a inconstitucionalidade de se vincular o salário mínimo para pagamento de adicional de insalubridade, o STF manteve o índice, até que seja promulgada lei que venha a regulamentar a mencionada base de cálculo.

Será que esse critério aplica-se aos empregados celetistas?

O que pode tornar inviável o exercício de algum direito já previsto em lei não será nunca a falta de uma norma (inclusive decreto) que a regulamente, mas, sim, a existência de alguma regra ou princípio que proíba ao juiz recorrer à analogia, aos costumes ou aos princípios de direito para suprir tal omissão.

No que se refere aos celetistas, não há qualquer proibição legal em se aplicar, por analogia, outros indexadores que serviam de base de cálculo para pagamento do adicional de insalubridade.

A afirmativa se justifica na medida em que as proibições constitucionais para a não aplicação da analogia aos servidores públicos não se aplicam aos empregados celetistas, que, como se sabe, não possuem remuneração vinculada a dotações orçamentárias.

Assim sendo, no que se refere especificamente aos empregados celetistas, a partir da aprovação da súmula vinculante n. ${ }^{\circ}$, tem-se por proibida a vinculação do salário mínimo para efeito de pagamento do adicional de insalubridade.

\footnotetext{
${ }^{21}$ Súmula 339 do STF: Não cabe ao Poder Judiciário, que não tem função legislativa, aumentar vendimentos de servidores públicos sob fundamento de isonomia.
} 
Contudo, mostra-se perfeitamente possível a aplicação, por meio da analogia, de outro índice para efeito de pagamento de adicional de insalubridade, não se aplicando, aos celetistas, o disposto na parte final da súmula vinculante $n .^{\circ} 4$.

É importante salientar que a súmula vinculante $n .^{\circ} 4$ apenas excluiu a possibilidade de aplicação do salário mínimo como base de cálculo para pagamento do adicional de insalubridade, mas o direito permaneceu intacto.

Assim, com relação aos celetistas, ao adotar outro parâmetro, o Poder Judiciário não estaria exercendo função legislativa, criando direito, mas, sim, cumprindo sua função, suprindo a omissão parcial do artigo 192 da CLT.

Como base de cálculo pode ser aplicado, por exemplo, o piso salarial, o salário básico, o salário normativo, devendo prevalecer a norma mais benéfica ao obreiro.

De qualquer maneira, é incontroverso que a súmula vinculante $n .^{\circ} 4$, como dito, não suprimiu o direito ao recebimento do adicional de insalubridade.

Desse modo, ainda que não prevaleça a posição acima citada, ainda assim subsistirá a possibilidade de se aplicar a súmula 228, em sua redação antiga.

É que, se a referida súmula não puder ser aplicada, não havendo regulamentação da base de cálculo do adicional de insalubridade, os trabalhadores simplesmente deixariam de receber o adicional de insalubridade, mesmo exercendo tais funções e fazendo jus à respectiva remuneração.

Outro fundamento que justifica esse pensamento é o fato de não existir em nosso ordenamento jurídico a possibilidade de reconhecimento de inconstitucionalidade por omissão no controle difuso, muito menos capaz de suprir a inércia do Poder Legislativo.

Desta feita, não há como um empregado ajuizar uma reclamação trabalhista requerendo o reconhecimento, de maneira difusa, da inconstitucionalidade por omissão do disposto na parte final do art. 192 da CLT, pois não pode um juiz, de primeiro grau, suprir a inércia do Poder legislativo, regulamentando a parte final do citado preceito legal.

Restaria assim, ao trabalhador que exerce função insalubre, ajuizar mandado de injunção, nos termos do disposto no art. 5º inc. LXXI, da Constituição Federal de 1988, sendo a proposição de competência exclusiva do STF, nos termos do disposto no art. $5^{\circ}$, inc. LXXI e art. 102, I, $q$, ambos da CF/88.

Todavia, consoante Silva (2000, p. 453) lamentavelmente o Supremo Tribunal Federal "vem dando ao instituto a função de uma ação pessoal de declaração de inconstitucionalidade por omissão". 
Sob a alegação de desrespeito à harmonia dos Três Poderes, no mandado de injunção, quando o STF reconhece a omissão, apenas dá ciência ao Poder competente para adoção das providências necessárias, nos termos do que dispõe o $§ 2^{\circ}$, art. 103, da CF/88.

Esse pensamento, no entanto, está em processo de intensa mutação. Atualmente há juristas que defendem que uma norma constitucional de eficácia limitada não pode ficar esperando a atitude do legislador infraconstitucional por tempo indeterminado.

\footnotetext{
Para ele, essas normas, por si sós, pouco valem. Sua eficácia, como o próprio nome indica, está limitada (ou condicionada, como queira) à edição da lei nela prevista. Se essa lei não for editada nunca, a norma constitucional nunca produzirá os efeitos previstos. A norma constitucional seria dirigida exclusivamente para o legislador. É óbvio que esse entendimento não pode prevalecer, sob pena de tornar a efetividade Constituição "refém" da vontade do Congresso Nacional. Ou seja: o legislador infraconstitucional terá mais poder do que o próprio legislador constituinte, o que é um absurdo (LIMA, 2010).
}

Exatamente por tal razão observa-se no STF, recentemente, uma alteração de orientação sobre a concretização de direitos fundamentais em sede de mandado de injunção, a ponto de, por exemplo, ser conferida eficácia plena ao direito de greve aos servidores públicos $^{22}$.

A esperança é que, com o tempo, seja consolidado esse entendimento no STF, especialmente quando se tratar de algum caso que necessite de tal decisão para efetivação de direitos constitucionalmente previstos, como se denota no problema tratado neste trabalho.

A questão a ser pensada, obviamente, cinge-se na regulamentação de como o Poder Judiciário poderia assim agir, em quais circunstâncias, em quais casos, o que necessita de um longo e sério debate.

\footnotetext{
${ }^{22}$ EMENTA: MANDADO DE INJUNÇÃO. ART. 5', LXXI DA CONSTITUIÇÃO DO BRASIL. CONCESSÃO DE EFETIVIDADE À NORMA VEICULADA PELO ARTIGO 37, INCISO VII, DA CONSTITUIÇÃO DO BRASIL. LEGITIMIDADE ATIVA DE ENTIDADE SINDICAL. GREVE DOS TRABALHADORES EM GERAL [ART. $9^{\circ}$ DA CONSTITUIÇÃO DO BRASIL]. APLICAÇÃO DA LEI FEDERAL N. 7.783/89 À GREVE NO SERVIÇO PÚBLICO ATÉ QUE SOBREVENHA LEI REGULAMENTADORA. PARÂMETROS CONCERNENTES AO EXERCÍCIO DO DIREITO DE GREVE PELOS SERVIDORES PÚBLICOS DEFINIDOS POR ESTA CORTE. CONTINUIDADE DO SERVIÇO PÚBLICO. GREVE NO SERVIÇO PÚBLICO. ALTERAÇÃO DE ENTENDIMENTO ANTERIOR QUANTO À SUBSTÂNCIA DO MANDADO DE INJUNÇÃO. PREVALÊNCIA DO INTERESSE SOCIAL. INSUBSSISTÊNCIA DO ARGUMENTO SEGUNDO O QUAL DAR-SE-IA OFENSA À INDEPENDÊNCIA E HARMONIA ENTRE OS PODERES [ART. 2O DA CONSTITUIÇÃO DO BRASIL] E À SEPARAÇÃO DOS PODERES [art. 60, § 4o, III, DA CONSTITUIÇÃO DO BRASIL]. INCUMBE AO PODER JUDICIÁRIO PRODUZIR A NORMA SUFICIENTE PARA TORNAR VIÁVEL O EXERCÍCIO DO DIREITO DE GREVE DOS SERVIDORES PÚBLICOS, CONSAGRADO NO ARTIGO 37, VII, DA CONSTITUIÇÃO DO BRASIL (MI 712/PA - MANDADO DE INJUNÇÃO. Rel. Min. Eros Roberto Grau. Julgamento: 25.10.2007. Órgão Julgador: Tribunal Pleno. Publicação: 31.10.2008. Disponível em: www.stf.jus.br. Aceso em: 08 mar. 2010).
} 


\section{CONCLUSÃO}

O trabalho tentou conceituar as súmulas vinculantes, qualificando-as como verbetes universalizantes e abstratos que, aprovados pelo STF, vinculam os demais órgãos do Poder Judiciário e da Administração Pública.

O estudo registrou duas características marcantes das súmulas vinculantes, uma, como o próprio nome denota, sua força vinculativa, e a outra o fato de ser aprovada e executada por um único órgão, o STF.

Também foram tecidas algumas críticas no que se refere às características assinaladas que, entretanto, não tiveram o condão de impedir o surgimento das súmulas vinculantes.

Foi consignado que, com o aparecimento das súmulas vinculantes, operou-se uma ruptura no sistema civil law, até então adotado pelo Brasil, de modo que, a partir delas, o sistema jurídico brasileiro passou a ser outro, diferente.

Este novo modelo jurídico é composto pelo extrato de nítidas raízes do sistema civil law, mesclado pela introdução de distorcidas essências do sistema common law.

Nesse sentido, o estudo evidenciou: entre a súmula vinculante e o caso concreto existe o juiz, pessoa a que o Estado confere o poder-dever de decidir.

A sentença do juiz, por sua vez, não pode ser proferida à luz de uma hermenêutica simplista, como se o simples tema da súmula vinculante se transformasse em um dogma imutável, pois as peculiaridades do caso concreto podem divergir e escapar à aplicação do verbete sumular.

Após essas considerações gerais, o trabalho fez emergir a polêmica jurisprudencial existente, em especial no STF, sobre a possibilidade, ou não, de se utilizar o salário mínimo como base para incidência de percentagem visando satisfazer adicional de insalubridade, ou como fator de indexação de referida parcela.

Neste particular, o trabalho pretendeu elucidar algumas dúvidas e pontos obscuros sobre a questão concernente à razão constitucional da proibição da vinculação do salário mínimo para fins de pagamento de adicional de insalubridade.

Também foi demonstrado que a súmula vinculante n. $^{\circ} 4$ repercutiu no Direito do Trabalho. Depois que a súmula vinculante n. 4 foi publicada, a $7^{\text {a }}$ Turma do C.TST entendeu por bem manter o salário mínimo como base para cálculo do adicional de insalubridade.

Todavia, o Pleno do C.TST não seguiu a citada orientação, nesse passo deu nova redação para a Súmula 228, instituindo o salário básico como base de cálculo para pagamento de adicional de insalubridade, salvo critério mais vantajoso previsto em instrumento coletivo. 
Entretanto, em virtude de decisão liminar proferida pelo Ministro presidente do STF, em sede da Reclamação n. 6.266, o novo enunciado da Súmula 228 acima citada foi suspenso.

Assim sendo, o C.TST voltou a adotar o entendimento pelo qual o salário mínimo continuará sendo utilizado como base de cálculo para pagamento do adicional de insalubridade, até que seja editada uma lei que venha instituir novo índice.

A esperança é que o problema seja solucionado de maneira definitiva por ocasião da decisão final que será proferida em sede da aludida Reclamação 6266.

Outra expectativa é que seja ajuizado mandado de injunção, e que o STF adote novo entendimento constitucional, de modo a suprir a mora do Poder Legislativo, instituindo nova base de cálculo.

Enquanto isso não acontece, pode-se dizer que a aprovação da súmula vinculante n. 4 não dirimiu todas as controvérsias acerca da polêmica anteriormente suscitada, inclusive não é possível precisar, com exatidão, qual deverá ser a solução.

\section{REFERENCIAS BIBLIOGRÁGICAS}

ANGELUCI, Regiane Alonso. Decisão Jurídica e Monopólio do Estado Responsabilidade do Estado e o Direito de Acesso à Justiça. Disponível em: <www2.oabsp.org.br/asp/comissoes/sociedade.../monopolio.pdf> Acesso em: 15 out. 2009.

ARAÚJO JUNIOR, Francisco Milton. A monetização do trabalho, antinomia constitucional e a base de cálculo do adicional insalubre. Disponível em: $<$ www.hocupacional.com.br/.../monetiza\%E7\%E3o\%20do\%20trabalho\%20insalubre.pdf $>$. Acesso em: 27 fev. 2010.

BRASIL. Supremo Tribunal Federal. Súmula Vinculante n. 4. Salvo nos casos previstos na Constituição, o salário mínimo não pode ser usado como indexador de base de cálculo de vantagem de servidor ou de empregado, nem ser substituído por decisão legal. Disponível em: <http://www.stf.jus.br> Acesso em: 15 out 2009.

BULOS, Uadi Lammêgo. Constituição Federal anotada. 8. ed. São Paulo: Saraiva, 2008. $1596 \mathrm{p}$.

CARIBÉ, Karla Virgínia Bezerra. A súmula vinculante no direito brasileiro: Uma incoerência do sistema jurídico. $<$ www.escola.agu.gov.br/.../sumula\%20vinculante_Karla\%20virginia.pdf $>$ Acesso em: 02 fev. 2010.

CONSELHO NACIONAL DE JUSTIÇA. A Justiça em números. 2003. Disponível em: $<$ http://www.cnj.jus.br/index.php?option=com_content $\& v i e w=\operatorname{article} \& i d=5242:$ justiemnos 20 03\&catid=206:justiem-nos\&Itemid=775>. Acesso em: 05 nov. 2009. 
BRASIL. Constituição da República Federativa do Brasil, de 5 de outubro de 1988. Disponível em: <http://www.planalto.gov.br> Acesso em: 12 dez. 2009.

CRUZ JUNIOR, Jeziel Rodrigues. As causas da morosidade judicial. Disponível em: <direito.newtonpaiva.br/revistadireito/.../14_Artigo\%20prof\%20Jeziel.pdf> Acesso em: 16 out. 2009.

DELGADO, José Augusto. A realidade, a justiça e o direito. Disponível em: <bdjur.stj.gov.br/xmlui/.../2011/.../A_Realidade_a_Justiça_e_o_Direito.pdf?> Acesso em: 05 nov. 2009.

DIDIER JUNIOR, Fredie. Ações constitucionais. 3. ed. Salvador: Juspodivm, 2009. 626 p.

DI PIETRO, Maria Sylvia Zanella. Direito administrativo. 12. ed. São Paulo: Atlas, 2000. $674 \mathrm{p}$.

FAIS, Juliana Marteli; SILVA, Leda Maria Messia da. Common law em relação ao direito brasileiro. <www.cesumar.br/pesquisa/periodicos/index.php/iccesumar/.../58 > Acesso em: 10 jan. 2010.

FERREIRA, Letícia Fazuoli, MOURA, Fernando Galvão. Sumulas vinculantes e o princípio do livre convencimento do juiz: evidente inconstitucionalidade. Disponível em: $<$ revistajuridica.fafibe.br/.../sumulas_vinculantes_e_o_principio_do_livre_con.pdf> Acesso em: 02 jan. 2010.

FOLLONI, André. Algumas anotações sobre a interpretação do direito. Disponível em: $<$ raizesjuridicas.up.edu.br/.../raizesjuridicas/.../10\%20Algumas\%20anotaes\%20sobre\%20a\%2 0interpretao\%20do> Acesso em: 08 fev. 2010.

GEMIGNANI, Tereza Aparecida Asta. 272 - Súmula Vinculante no 4: Tertius Genus no controle da constitucionalidade? Disponível em: <www.epm.sp.gov.br> . Acesso em: 05 mar. 2010.

GOUVEIA, Alessandro Samartin. Sumula vinculante: um limite e um convite à vontade do poder. Disponível em: <www.direitodoestado.com/.../REDE-14-ABRIL-2008ALESSANDRO\%20GOUVEIA.PDF> Acesso em: 02 jan. 2010.

HARTMANN, Rodolfo Kronemberg. A súmula vinculante a lei n. 11.417/06. Disponível em: <www.jfrj.gov.br/Rev_SJRJ/num20/artigos/artigo_04.pdf >. Acesso em: 05 jan. 2010.

LEMOS, Alessandro Medeiros. Adicional de insalubridade. Base de cálculo pós Súmula Vinculante $n^{0} 4$ do STF. O que muda com a fixação do novo salário mínimo? Disponível em: <jus2.uol.com.br > ... > adicional de insalubridade>. Acesso em: 01 mar. 2010.

LIMA, Fabíola Bessa Salmito. Alcance material e temporal da Súmula Vinculante n. 4 do STF. Disponível em:< www.procuradoria.al.gov.br/.../Fabiola\%20Bessa\%20Salmito\%20Lima.pdf> Acesso em: 27 fev. 2010. 
LIMA, George Marmelstein. Critica à classificação de José Afonso da Silva acerca da aplicabilidade e eficácia das normas constitucionais. Disponível em: <www.georgemlima.xpg.com.br/critica.pdf>. Acesso em: 08 mar. 2010.

LOBO, Arthur Mendes. Breves comentários sobre a regulamentação da súmula vinculante. Disponível em: <revistajuridica.fafibe.br/breves_comentário_sobre a regulamentação da. pdf> Acesso em: 25 out. 2009.

LOPES, Natália Branco. A súmula vinculante como meio viabilizador da razoável duração do processo: obstáculo ou instrumento para a efetivação do acesso à justiça? Disponível em: <www2.uel.br/.../Natalia_Branco_Lopes_Sumula_Vinculante.pdf> Acesso em: 01 nov. 2009.

MAUÉS, Antonio Moreira; FONSECA, Mônica Maciel Soares; REGO, Lorena de Paula da Silva. Súmula vinculante e direito à igualdade. Disponível em: <http://bdjur.stj.gov.br/jspui/bitstream/2011/18668/2/Súmula_Vinculante_e_Direito.pdf>. Acesso em: 25 out. 2009.

Idem. Acesso em: 02 fev. 2010.

MEIRELLES, Hely Lopes. Direito administrativo brasileiro. 36. ed. São Paulo: Malheiros, 2000. $872 \mathrm{p}$.

MELLO, Rafael Corte; PACHECO, Antônio Marcelo. Da decisão judicial: um conflito entre o ato de fundamentar e a ação de motivação como uma crise de legitimidade do Poder Judiciário no Brasil. Disponível em: $<$ www.conpedi.org/.../hermeneutica_antonio_pacheco_e_rafael_melo.pdf> Acesso em: 05 fev. 2010.

MENDES, Gilmar Ferreira. A declaração de inconstitucionalidade sem a pronúncia de nulidade e a declaração de inconstitucionalidade de caráter restritivo ou limitativo no direito brasileiro. Disponível em: <www.direitodoestado.com/.../REDE-13-JANEIRO-2008GILMAR\%20MENDES.pdf> Acesso em: 10 fev. 2010.

NASCIMENTO, Valéria Heinicke. $O$ adicional de insalubridade e a Súmula Vinculante n. 4 do STF. Disponível em: <www.trt4.gov.br/ItemPortlet/download/2862/08_de_junho.pdf>. Acesso em: 01 mar. 2010.

PEDRON, Flávio Quinaud. Um olhar reconstrutivo da modernidade e da "crise de judiciário": a diminuição dos recursos é mesmo uma solução? Disponível em: <bdjur.stj.gov.br. um olhar reconstrutivo da modernidade e da crise de judiciário: a diminuição dos recursos é mesmo uma solução?.pdf> Acesso em: 28 out. 2009.

PIMENTA, José Roberto Freire. Súmulas com efeito vinculante: uma abordagem crítica. Disponível em: <www.mg.trt.gov.br/escola/download/revista/.../Jose_Pimenta.pdf> Acesso em: 07 jan. 2010.

ROEDER FILHO, Nivaldo; ROEDER NETO, Guilherme; VASQUES, Marcos Roberto de alburquerque. Laudos periciais de insalubridade. Disponível em: <www.saudeetrabalho.com.br/download/laudos-roeder.pdf> Acesso em: 25 fev. 2010. 
SILVA, José Afonso da. Curso de direito constitucional positivo. 17 ed. São Paulo: Malheiros, 2000. 871 p.

Site. <www.stf.jus.br>. Acesso em: 08 mar. 2010.

STRECK, Lenio Luiz apud BONAVIDES, Paulo. O efeito vinculante das súmulas e o mito da efetividade: uma critica hermenêutica. In Constituição e democracia - estudos em homenagem ao professo J.J. Gomes Canotilho. São Paulo: Malheiros, 2008. 528 p.

TABELA 1. Taxa de investimento estrangeiro direito em relação ao PIB. Disponível em $<w w w . c o r e c o n-r j . o r g . b r / S e r i e s \_B P . a s p ? . . . I n v e s t i m e n t o+e s t r a n g e i r o>$. Acesso em: 05 nov. 2009. 